\title{
Assessing the cost-effectiveness of invasive species management: a decision tool for biodiversity conservation
}

\author{
$\underline{\text { K.J. Davis }}^{\text {a,b }}$, M.E. Kragt ${ }^{a}$ and D.J. Pannell ${ }^{a}$ \\ ${ }^{a}$ Centre for Environmental Economics and Policy, School of Agricultural and Resource Economics, \\ University of Western Australia, Perth, Australia. \\ ${ }^{b}$ Centre of Excellence for Environmental Decisions, School of Biological Sciences, University of \\ Queensland, Brisbane, Australia. \\ Email:k.davis@uq.edu.au
}

\begin{abstract}
Invasive species threaten biodiversity in Australia. One of these species is the introduced root pathogen Phytophthora cinnamomi, which harms native and commercial plant species. Disease caused by this pathogen was listed as a key threatening process under the Commonwealth's Environment Protection and Biodiversity Conservation Act in 2000. There is considerable uncertainty regarding the best management strategies to address invasive species like Phytophthora cinnamomi; particularly where the efficacy of control methods is unknown. How should environmental managers decide whether management strategies are worthwhile or cost-effective? We demonstrate the use of a tool that can address these management challenges: the Investment Framework for Environmental Resources (INFFER). INFFER was designed to help environmental managers achieve the most valuable environmental outcomes with the limited resources they have available. The framework involves a systematic assessment of the trade-offs between variables such as asset value, likelihood that private individuals will adopt management or behavioural changes, delays in the realisation of benefits, and sources of uncertainty due to potential technical failure or socio-political risks. We present an application of INFFER to assess the cost-effectiveness of management strategies to address Phytophthora cinnamomi in the Fitzgerald River National Park, a national park in the South-West Botanical Province of Western Australia. The Fitzgerald River National Park is one of the largest parks in Australia, and has high conservation value because of its high floral diversity and numbers of endemic species. The model was developed in collaboration with park stakeholders, including park rangers, management and research officers, and members of a local natural resource management group. We found that despite uncertainty regarding the efficacy of existing containment and eradication methods, management strategies aimed at containing existing Phytophthora cinnamomi infestations and preventing future infestations, resulted in significantly greater benefits than costs (Benefit: Cost Index =3.02). This result supports investment of public conservation funds to control Phytophthora cinnamomi in the Fitzgerald River National Park. A sensitivity analysis identified the need for better biophysical data to quantify the impact of management works, and demonstrated how uncertain funding environments prevent confidence in the accomplishment of project goals, through an inability to assure the future maintenance and upkeep of management works. Our analysis demonstrates the importance of using a rigorous decision support tool like INFFER to assess investment decisions when there is uncertainty regarding conservation benefits.
\end{abstract}

Keywords: Benefit-cost analysis, biodiversity conservation, cost-effectiveness, natural resource management, stakeholder engagement 


\section{INTRODUCTION}

Invasive species threaten biodiversity globally and nationally. One invasive species which has had devastating effects on Australia's native and commercial plant species is Phytophthora cinnamomi, an introduced root pathogen (Cahill et al. 2008). Phytophthora cinnamomi prevents infected plant species from drawing up water and nutrients, resulting in the death of susceptible plants (Cahill et al. 2008; Lewis and Colquhoun 2000). Mortality of susceptible plant species affects the structure and function of plant communities with detrimental impacts on dependent fauna (Cahill et al. 2008). The result is a loss of biodiversity (Shearer et al. 2009). Disease caused by Phytophthora cinnamomi was listed as a key threatening process under the Commonwealth's Environment Protection and Biodiversity Conservation Act in 2000 (DEH 2002). Phytophthora cinnamomi is spread in infested soil by root-to-root contact, human and non-human vectors and by surface and subsurface water flows (Dunstan et al. 2008; Shearer et al. 2007). Introduced species like Phytophthora cinnamomi are considered the second greatest threat to biodiversity after habitat destruction (Simberloff et al. 2005).

Protecting biodiversity is a challenge when landscapes are threatened by invasive species. This challenge is made more complex because there is often limited information and considerable uncertainty regarding the biology of invasive species and the efficacy of control measures, as is the case with Phytophthora cinnamomi. Natural resource managers are faced with the difficult task to identify effective management actions while considering budget limitations as well as the values and capacities of stakeholders. From a social welfare perspective, policy makers will aim to maximise the benefits from public investment in conservation management. This requires an assessment of the costs of conservation actions versus the likely benefits from managing an invasive species like Phytophthora cinnamomi.

In this paper, we demonstrate a tool that can help environmental managers decide which conservation strategies are most worthwhile and most cost-effective. This tool is the Investment Framework for Environmental Resources (INFFER). We develop the INFFER framework to assess the cost-effectiveness of management strategies to address Phytophthora cinnamomi in the Fitzgerald River National Park (FRNP), Western Australia. The model was parameterized with input from stakeholders, including from park rangers, management and research officers, and members of a local natural resource management group.

\section{MODELLING FRAMEWORK}

INFFER is a tool to inform environmental investment decisions (Pannell et al. 2012). The framework was designed to help natural resource management bodies plan projects in a way that delivers the most valuable environmental outcomes for the available resources. INFFER can identify which projects have the highest benefit to cost ratios, defined as benefit cost index (BCI). As a framework, INFFER has been widely used in Australia and overseas, and is well documented (see www.inffer.org). Previous applications of INFFER include an assessment of potential changes in land use and land management to achieve nutrient reductions targets in the Gippsland Lakes, and the identification of improved priorities for land-use change in Victoria (Pannell et al. 2012; Roberts et al. 2009)

Modelling with INFFER is a stakeholder driven process. The BCI is generated by working through the steps of the INFFER Project Assessment Form (PAF), which lays out the costs and benefits of different management scenarios (see Appendix A). The INFFER model includes a comprehensive set of relevant variables that influence the cost-effectiveness of environmental projects through its BCI calculations as follows:

$$
B C I=\frac{V \times W \times F \times A \times B \times P \times G \times D F_{B}(L) \times \text { years }}{C+P V(M)}
$$

This takes into account the significance of the asset $(V)$, which is based on environmental, economic and community considerations; future reduction in damage to the asset that would result from management works $(W)$; the likelihood that private individuals will adopt changes proposed by a project ( $A$ and $B$ ); delays in the realisation of project benefits ( $L$ - discounted with factor $D F$, see Appendix B); and sources of uncertainty due to potential technical failure or socio-political risks $(F, B, P, G)$. The framework accounts for short-term costs of the management works $(C)$ and annual maintenance costs $(M-$ discounted into Present-day Values, see Appendix B). The BCI is calculated over the time frame in which management works are expected to achieve a desired goal (years). See Appendix B for a full explanation of this Benefit:Cost Index. 


\section{STUDY APPLICATION}

Our analysis is based in the FRNP (Figure 1). The FRNP is located in the South-West Botanical Province of Western Australia, which is one of the world's 25 biodiversity hotspots (Myers and Mittermeier 2000). The park contains $\sim 20 \%$ of the total number of plant species in WA; 62 of which are endemic to the park, with a further 48 more or less confined to the park boundaries (Cahill et al. 2008; Chapman and Newby 1995). The park is threatened by Phytophthora cinnamomi, which has been identified as a significant management concern (CPSM 2009; Moore et al. 1991). The park is particularly at risk due to the area's favourable environmental conditions, and the large number of plant species which are vulnerable to the pathogen (Cahill et al. 2008; Lewis and Colquhoun 2000); estimates suggest that $40 \%$ of plant species in the South-West Botanical Province are susceptible to Phytophthora cinnamomi, and 14\% are highly susceptible (Shearer et al. 2004). Cahill et al. (2008) have speculated that infestation of the park by Phytophthora cinnamomi could be the "greatest biodiversity catastrophe in Australia".

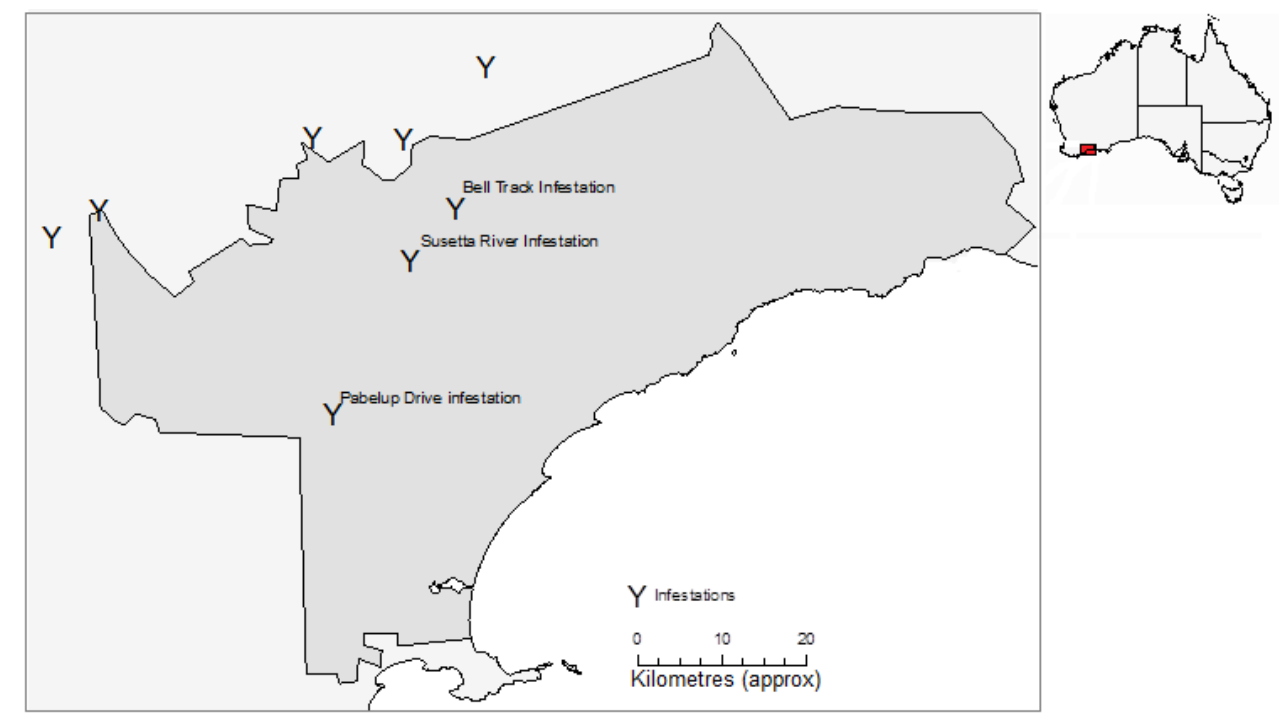

Figure 1. Fitzgerald River National Park (shaded) in the Southwest of Western Australia (Moore et al. 1991). Approximate locations of existing Phytophthora cinnamomi infestations are indicated.

In 2011, less than 1\% of the area of the park was infested with Phytophthora cinnamomi (Figure 1) (Dunne et al. 2011). The park's manager, the Department of Environment and Conservation (DEC, now Department of Parks and Wildlife) had employed various management strategies to contain these infestations. These management strategies included: fencing of the infested sites to prevent animals acting as disease vectors; phosphite and herbicide application; and hydrological engineering works (Dunne et al. 2011). Management funds are limited so there is a need to identify management strategies which will be most cost-effective in addressing Phytophthora cinnamomi in the park.

\subsection{Data}

To conduct the INFFER assessment, information was needed from DEC and other stakeholder groups. To secure DEC support for the analysis it was necessary to brief DEC managers regarding the scope of the investigation, and its likely ramifications, before further cooperation could be authorised. Once this was given, meetings were conducted with staff from the DEC Science Division and DEC office staff in Albany to discuss current and potential new management strategies, the significance of the park's biodiversity, and the severity of the threat posed by Phytophthora cinnamomi. Further input regarding the significance of the park and perceptions of control strategies was sought from two more stakeholder groups: South Coast Natural Resource Management (a local NRM group), and park rangers. Finally, data was collected during a field visit to examine current dieback management activities and to assess what information on Phytophthora cinnamomi was available to park visitors. Strategies that have been used to manage Phytophthora cinnamomi in other infested regions, including hygiene measures and quarantine of the infected area (Podger 1999), were also reviewed.

\subsection{Management scenario}

The management goal that was identified during discussion with staff from DEC was to contain existing Phytophthora cinnamomi outbreaks, and prevent further infestations. The time frame for achieving the 
management goal was 20 years. This was expected to be a sufficient time frame for high intensity but low frequency weather events to occur, which would test the containment works in the park. The potential management works, up-front and maintenance costs, as well as risks and benefits of this management scenario were identified. Scenario A was based on the management works that DEC was planning to employ (Table 1). Scenario B involved a more ambitious, larger-scale response to Phytophthora cinnamomi that would eradicate current infestations. In scenario B, stricter hygiene procedures would be enforced upon entry into the park.

Table 1. Proposed management works to address Phytophthora cinnamomi in the FRNP.

\begin{tabular}{|l|l|}
\hline \multicolumn{1}{|c|}{ Scenario A } & \multicolumn{1}{|c|}{ Scenario B } \\
\hline Monitoring of previous containment strategies & Limit park entrances to four \\
\hline $\begin{array}{l}\text { Installation of additional surface geo-textile membranes at Bell Track } \\
\text { infestation }\end{array}$ & Park entrances to be manned by DEC rangers \\
\hline $\begin{array}{l}\text { Develop fumigation techniques for spot eradication at Bell Track and } \\
\text { Pabelup Drive infestations }\end{array}$ & Every vehicle inspected/cleaned on entry \\
\hline Survey and interpretation program & $\begin{array}{l}\text { Four automatic car-wash systems for public use at } \\
\text { park entrances }\end{array}$ \\
\hline Upgrades to infrastructure, including high security gates & $\begin{array}{l}\text { Educational material on dieback at all four park } \\
\text { entrances }\end{array}$ \\
\hline Assess the effectiveness of DEC's current hygiene practices & Fence park in its entirety \\
\hline Phosphite application & Eradiation of existing infestations \\
\hline Maintenance of existing infrastructure & \\
\hline
\end{tabular}

\section{RESULTS}

In this paper, we present the results of Scenario A, which represented DEC's management strategies at the time. The parameter values required to calculate the INFFER BCI (Equation 1) for management scenario A were estimated by two DEC staff members with experience and expert knowledge of Phytophthora cinnamomi and the FRNP. The base-case values for both scenarios were decided upon in conference with David Pannell, the developer of the INFFER framework, to ensure that responses were consistent with the intended meanings of questions, and appeared reasonable in light of responses used in previous applications of the framework (Table 2).

Table 2. Base-case parameter values for management scenario $\mathrm{A}$

used to calculate a benefit cost index using the INFFER framework. Note that parameter $B$, (Adverse adoption) was not applicable to this management scenario, and hence set to 1 to negate its effect in the multiplicative BCI equation.

\begin{tabular}{|c|c|c|c|c|c|c|c|c|}
\hline $\begin{array}{c}\text { Value } \\
(V)\end{array}$ & $\begin{array}{c}\text { Impact of } \\
\text { works }(W) \\
1-100\end{array}$ & $\begin{array}{c}\text { Technical } \\
\text { feasibility } \\
(F)\end{array}$ & $\begin{array}{c}\text { Adoption } \\
(A)\end{array}$ & $\begin{array}{c}\text { Socio- } \\
\text { political } \\
\text { risks }(P) \\
0-1\end{array}$ & $\begin{array}{c}\text { Long-term } \\
\text { funding }(G) \\
0-1\end{array}$ & $\begin{array}{c}\text { Lag }(L) \\
(0-100 \mathrm{yrs})\end{array}$ & $\begin{array}{c}\text { Up-front } \\
\text { cost }(C) \\
(\$ \mathrm{mil})\end{array}$ & $\begin{array}{c}\text { Maintenance } \\
\text { cost }(M) \\
(\$ \mathrm{mil} / \mathrm{yr})\end{array}$ \\
\hline 40 & 0.1 & 0.82 & 0.7 & 0.97 & 0.5 & 10 & 0.24 & 0.4 \\
\hline
\end{tabular}

The value for the park was set at $V=40$, which represents a very high state significance. The future reduction in damage to the park attributable to management works was estimated by DEC staff members to be quite low at 0.1 . There was little risk of technical failure or socio-political risks (high $F$ and $P$ ), but adoption of the measures by visitors was estimated to be average $(A=0.7)$. Based on the parameters described in Table 2 , we calculated the benefit cost index for management scenario A. The BCI for this management scenario was 3.02. This indicates a ratio of benefits to costs of three to one. This shows that, despite uncertainty regarding the efficacy of existing containment and eradication methods, a strong business case could be made to increase public investment to reduce biodiversity loss caused by Phytophthora cinnamomi. If no management works would be undertaken, it was estimated that the value of the park would decrease by $20 \%$ over the next 20 years through new infestations and further spread of current infestations. The park's value would decrease by only $10 \%$ if management works were undertaken $(W=0.2-0.1=0.1$, Table 2$)$. This reduction would be achieved at a total cost (present value) of $\$ 4.52$ million (Table 3).

Table 3. Results from the INFFER benefit cost index (BCI) ${ }^{\dagger}$ analysis for scenario A.

Present value of maintenance costs ${ }^{\ddagger}$ Present value of total costs Benefit : Cost Index

4.28 (\$ million) $\quad 4.52(\$$ million $) \quad 3.02$

${ }^{+} \mathrm{A}$ BCI $>1$ indicates that project benefits are greater than costs. ${ }^{\ddagger}$ Maintenance costs will be spread over a 20 year period. 


\subsection{Sensitivity analysis}

A sensitivity analysis of the baseline parameterisation was conducted to determine the robustness of the results in scenario A. Each model parameter was varied across an uncertainty range, based on the magnitude of the discrepancy between the estimates of the two DEC staff, or as considered appropriate based on previous applications of INFFER (Pannell, D 2011, pers. comm.).

Table 4 shows the sensitivity of model results to changes in individual parameters (a change in only one parameter was considered at a time - all others held constant). BCI results are given for the lowest and highest considered parameter value. The sensitivity analysis shows that model results were most sensitive to the "impact of works" parameter (difference between the high and low BCI values $=8.2$ ). Results were also sensitive to the three cost parameters: availability of long-term funding (4.8), maintenance costs (2.5), and park value (1.9).

\begin{tabular}{|c|c|c|c|}
\hline \multirow[b]{2}{*}{ Parameter changed } & \multicolumn{2}{|c|}{ BCI } & \multirow{2}{*}{$\begin{array}{l}\text { Absolute } \\
\text { difference }\end{array}$} \\
\hline & Low & High & \\
\hline Base-case scenario & \multicolumn{2}{|c|}{3.02} & \\
\hline Socio-political risk & 2.7 & 3.1 & 0.5 \\
\hline Lag & 3.9 & 2.4 & 1.5 \\
\hline Adoption & 2.2 & 3.9 & 1.7 \\
\hline Technical feasibility & 1.5 & 3.2 & 1.7 \\
\hline Value & 1.9 & 3.8 & 1.9 \\
\hline Maintenance cost & 4.7 & 2.2 & 2.5 \\
\hline Long-term funding & 0.6 & 5.4 & 4.8 \\
\hline Impact of works & 0.9 & 9.1 & 8.2 \\
\hline
\end{tabular}

\section{DISCUSSION}

The results of this analysis support the investment of public conservation funds to control Phytophthora cinnamomi in the FRNP, as management resulted in significantly greater benefits than costs $(\mathrm{BCI}>1)$. This result is based on the integration of information provided by various experts and stakeholders who were consulted during the project, combined with information from existing technical research.

The importance or validity of using a rigorous decision support tool like INFFER when there is uncertainty regarding conservation benefits has previously been confirmed by Pannell (2009) and Murdoch et al. (2007). Pannell (2009), in particular, conducted extensive simulations of hypothetical prioritisation decisions, and concluded that the rigour of the economic model used to assess investment decisions can be more important than the accuracy of the estimation of the variables.

When making conservation investment decisions, NRM managers often face major information gaps, or lack relevant expertise or the resources necessary to incorporate pertinent economic, social and biophysical data (Seymour et al. 2008). In particular, Murdoch et al. (2007) have remarked that estimates of conservation benefits are often based on educated guesses. The use of an investment decision tool like INFFER makes this process transparent, allowing estimations to be scrutinised. The easily laid out interface helps natural resource managers to systematically evaluate the available information, to query their assumptions, and to reveal knowledge uncertainties.

The sensitivity analysis undertaken in this investigation identified that the BCI of management works in scenario A was sensitive to changes in the "impact of works" and cost parameters. To ensure robust management decisions, better biophysical data to quantify the impact of management works may be needed. Results also suggest that uncertain funding environments prevent confidence in the accomplishment of project goals, because resources for the upkeep of management works and future maintenance activities cannot be guaranteed. The key uncertainties in the model identify priorities for further research, and management/structural changes which are needed to accurately determine the cost-effectiveness of management strategies to address Phytophthora cinnamomi. 


\section{REFERENCES}

Cahill, D.M., J.E. Rookes, B.A. Wilson, L. Gibson, and K.L. McDougall (2008). "TURNER REVIEW No. 17. Phytophthora cinnamomi and Australia's biodiversity: impacts, predictions and progress towards control." Australian Journal of Botany, 56, 279-310.

Chapman, A., and K.R. Newby (1995). "A biological survey of the Fitzgerald area, Western Australia. (CALM Science, Supplement 3)." Department of Conservation and Land Management.

CPSM (Centre for Phytophthora Science and Management) (2009). "Dieback Management Issue Based Performance Assesment."

DEH (Department of Environment and Heritage) (2002). "Threat Abatement Plan for Dieback caused by the root-rot fungus Phytophthora cinnamomi."

Dunne, C.P., C.E. Crane, D. Biddulph, M. Lee, G. Young, T. Massenbauer, S. Barrett, S. Comer, G.J.C. Freebury, D.J. Utber, M.J. Grant, and B. Shearer (2011). "A review of the catchment approach techniques used to manage Phytophthora cinnamomi infestation of native plant communities of the Fitzgerald River National Park on the south coast of Western Australia " New Zealand Journal of Forestry Science, 41, S121-S132.

Dunstan, W.A., T. Rudman, B. Shearer, N. Moore, T. Paap, M. Calver, R. Armistead, M.P. Dobrowolski, B. Morrison, K. Howard, E. O'Gara, C. Crane, B. Dell, P.A. O’Brien, J. McComb, and G.E.S.J. Hardy (2008). "Research into natural and induced resistance in Australian native vegetation of Phytophthora cinnamomi and innovative methods to contain and/or eradicate within localized incursions in areas of high biodiversity in Australia. Eradication of Phytophthora cinnamomi from spot infections in native plant communities in Western Australia and Tasmania."

Lewis, S., and I.J. Colquhoun (2000). "Managing Phytophthora dieback. Guidelines for Local Government." The Dieback Working Group, Perth.

Moore, S., M. Cavana, K. Gillen, C. Hart, S. Hopper, K. Orr, and W. Schmidt. (1991). "Fitzgerald River National Park Management Plan 1991-2001." Department of Conservation and Land Management, Perth.

Murdoch, W., S. Polasky, K.A. Wilson, H.P. Possingham, P. Kareiva, and R. Shaw (2007). "Maximizing return on investment in conservation." Biological Conservation 139, 375-388.

Myers, N., and R.A. Mittermeier (2000). "Biodiversity hotspots for conservation priorities. (cover story)." Nature, 403 (6772), 853.

Pannell, D.J. 2009. "INFFER (Investment Framework for Environmental Resources).” INFFER Working Paper 0901. University of Western Australia, Perth.

Pannell, D.J., A.M. Roberts, G. Park, J. Alexander, A. Curatolo, and S.P. Marsh (2012). "Integrated assessment of public investment in land-use change to protect environmental assets in Australia." Land Use Policy, 29, 377-387.

Podger, F. (1999). "A National Overview of Phytophthora cinnamomi in Australia: supplementary information to accompany the draft national Threat Abatement Plan." Environment Australia, Natural Heritage Trust, Australia.

Roberts, A.M., D.J. Pannell, G. Doole, and O. Vigiak (2009). "Report on the Gippsland Lakes INFFER Analysis." In INFFER Working Paper 1001. University of Western Australia.

Seymour, E., D. Pannell, A. Roberts, S. Marsh, and R. Wilkinson (2008). "Decision-making by Regional Bodies for Natural Resource Management in Australia: Current Processes and Capacity Gaps." Australasian Journal of Environmental Management, 15, 211 -221.

Shearer, B.L., C.E. Crane, S. Barrett, and A. Cochrane (2007). "Phytophthora cinnamomi invasion, a major threatening process to conservation of flora diversity in the South-west Botanical Province of Western Australia." Australian Journal of Botany, 55, 225-238.

Shearer, B.L., C.E. Crane, and A. Cochrane (2004). "Quantification of the susceptibility of the native flora of the South-West Botanical Province, Western Australia, to Phytophthora cinnamomi." Australian Journal of Botany, 52, 435-443.

Shearer, B.L., C.E. Crane, R.G. Fairman, and C.P. Dunne (2009). "Ecosystem dynamics altered by pathogenmediated changes following invasion of Banksia woodland and Eucalyptus marginata forest biomes of south-western Australia by Phytophthora cinnamomi." Australasian Plant Pathology, 38, 417-436.

Simberloff, D., I.M. Parker, and P.N. Windle (2005). "Introduced Species Policy, Management, and Future Research Needs." Frontiers in Ecology and the Environment, 3, 12-20.

\section{APPENDIX A}

Our analysis was completed using the INFFER Project Assessment Form (see Figure B below). 


\section{inffer Project Assessment Form}

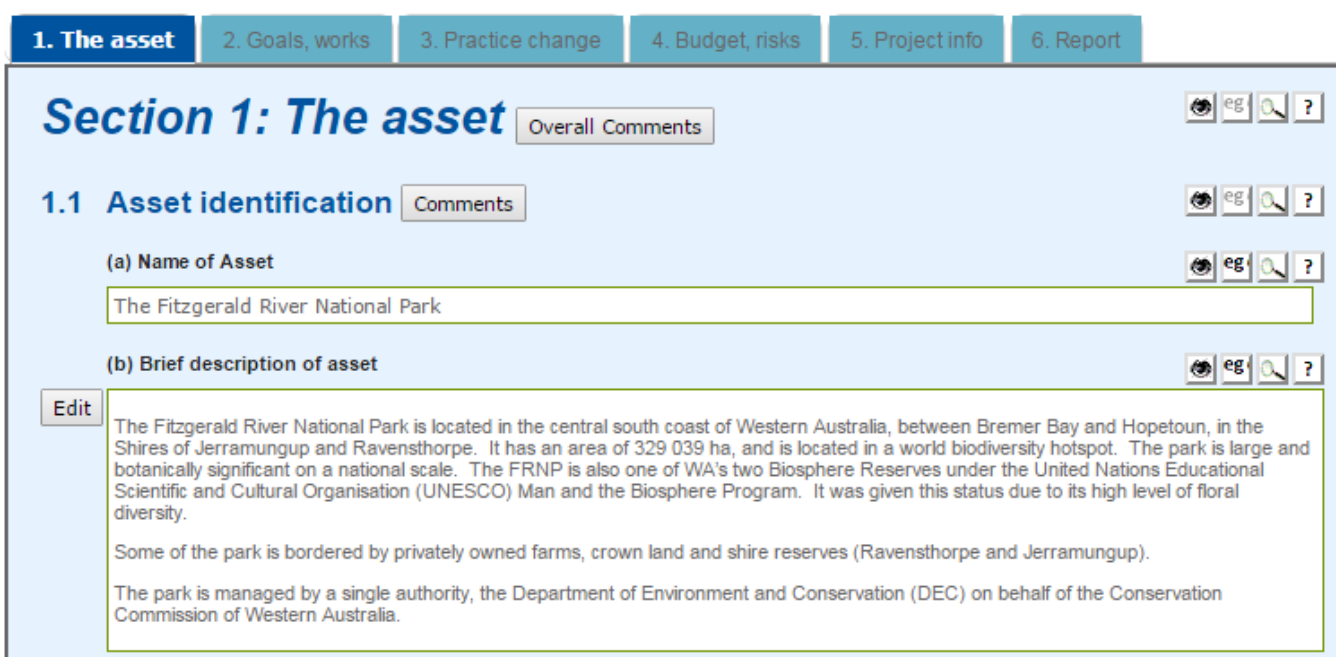

Figure B. INFFER Project Assessment Form.

\section{APPENDIX B}

Our analysis is based in the FRNP (see Figure 1). The FRNP is located in the South-West Botanical Province of Western Australia, which is one of the world's 25 biodiversity hotspots (Myers and Mittermeier 2000).

Calculation of Benefit: Cost Index (BCI) used in INFFER (Pannell et al, 2012)

$B C I=\frac{V \times W \times F \times A \times B \times P \times G \times D F_{B}(L) \times \text { years }}{C+P V(M)}$

where:

$V=\quad$ significance (or value) of the asset (score out of 100)

$W=$ multiplier for proportional impact of works on asset value (0-1)

$F=$ multiplier for technical feasibility risk (probability that the project will not fail due to problems with technical feasibility) (0-1)

$A=$ multiplier for adoption of changed management by private landholders (proportion of adoption level required to achieve goal) (0-1)

$B=$ multiplier for risk of adoption of adverse practices (probability that the project will not fail due to adverse adoption) (0-1)

$P=$ probability that socio-political factors will not derail the project, and that required changes will occur in other institutions (0-1)

$G=$ probability that essential funding subsequent to this project will be forthcoming $(0-1)$

$D F_{B}=$ discount factor for benefits (proportion), depending on $L$, where $D F=1 /(1+r)^{L}$, given real discount rate $(r)$ of 0.05

$L=$ time lag until the majority of anticipated benefits from the project occur (0-100 years)

$C=$ short-term cost of current project ( $\$$ million in total, over the three-to-five-year life of the project)

$P V=$ present value function to convert future costs to equivalent present-day values. For example, assuming a real discount rate $(r)$ of 0.05 and that the time frame for paying ongoing costs is 20 years, and that these costs commence four years after the start of the project, $\mathrm{PV}(\mathrm{M}+\mathrm{E})=10.7 \mathrm{x}(\mathrm{M}+\mathrm{E})$.

$M=$ annual cost of maintaining outcomes (\$ million per year, additional to short-term costs). 